\title{
RECHTSREGEL
}

\section{KEDUDUKAN DAN KEWENANGAN KOMISI PENYIARAN INDONESIA DENGAN LEMBAGA SENSOR FILM MENGENAI KEPASTIAN HUKUM BIDANG PERFILMAN}

\author{
Asip Suyadi \\ Fakultas Hukum, Universitas Pamulang \\ Email :asipsuyadi25@gmail.com
}

Received: Jan 2019 / Revised: Jun 2019 / Accepted: Ags 2019

\begin{abstract}
Atas dasar keinginan untuk mewujudkan Bidang Penyiaran yang tetap sejalan dengan Undang-Undang Dasar Negara Republik Indonesia dan agar bebas dari campur tangan pemodal maupun kepentingan kekuasaan, maka melalui Undang-Undang Nomor 32 Tahun 2002 tentang Penyiaran lahirlah Komisi Penyiaran Indonesia yang tugasnya memantau bagaimana jalannya Penyiaran di Indonesia. Tetapi dari Undang-Undang Nomor 33 Tahun 2009 tentang Perfilman lahirlah lembaga yang dinamakan Lembaga Sensor film yang keabsahannya dituangkan dalam Peraturan Pemerintah Nomor 18 Tahun 2014. Adanya lembaga yang berbeda tetapi memiliki kewenangan yang sama sehingga terdapat peraturan yang tumpang tindih antara Komisi Penyiaran Indonesia dengan Lembaga Sensor Film terkait kepastian hukum dalam bidang perfilman yang terfokus pada penyensoran. Tumpang tindih yang dimaksud adalah mengenai film yang sudah mendapatkan Surat Tanda Lulus Sensor dari Lembaga Sensor Film tetapi tidak dapat ditayangkan di televisi yang merupakan ranah dari Komisi Penyiaran Indonesia karena dalam film tersebut dianggap memuat konten yang tidak pantas.
\end{abstract}

Kata kunci : Komisi Penyiaran Indonesia, Lembaga Sensor Film, Kepastian Hukum

\section{ABSTRACT}

On the basis of the desire to realize the Broadcasting Sector which remains in accordance with the Constitution of the Republic of Indonesia and to be free from investor interference and also for the sake of interest, then through Act No. 32 of 2002 concerning Broadcasting was born the Indonesian Broadcasting Commission which was tasked with moving broadcasting roads in Indonesia. But from Law 
Number 33 of 2009 concerning Film was born an institution called the Film Censorship Institution whose validity was set forth in Government Regulation Number 18 of 2014. The existence of different Film Censorship institutions related to legal certainty in the field of film focused on censorship. The overlap discussed is about films that have received a Sensor Pass Certificate from the Film Censorship Institution but cannot be broadcast on television which is the realm of the Indonesian Broadcasting Commission because in this film it is called inappropriate content.

Keywords: Indonesian Broadcasting Commission, Film Censorship Institute, Legal Certainty

\section{PENDAHULUAN}

Perkembangan masyarakat, baik secara ekonomi, politik, dan sosial budaya, serta pengaruh globalisme dan lokalisme, menghendaki struktur organisasi negara lebih responsif terhadap tuntutan mereka serta lebih efektif dan efsien dalam melakukan pelayanan publik dan mencapai tujuan penyelenggaraan pemerintahan. Muncul kemudian lembaga-lembaga negara sebagai bentuk eksperimentasi kelembagaan yang dapat berupa dewan (council), komisi (commission), komite (committee), badan (board), atau otorita (authority). Selain lembaga-lembaga Negara yang dapat dikategorikan sebagai organ utama atau primer, ada pula yang merupakan organ pendukung atau penunjang yang dibentuk berdasarkan amanat undang-undang atau peraturan yang lebih rendah, seperti Peraturan Pemerintah, Peraturan Presiden atau Keputusan Presiden.

Salah satu lembaga Negara tersebut adalah Komisi Penyiaran Indonesia (KPI). Undang-Undang Nomor 32 Tahun 2002 tentang Penyiaran merupakan dasar utama bagi pembentukan Komisi Penyiaran Indonesia (KPI). Fokusnya adalah pengelolaan sistem penyiaran yang merupakan ranah publik harus dikelola oleh sebuah badan independen yang bebas dari campur tangan pemodal maupun kepentingan kekuasaan. Berbeda dengan semangat dalam Undang-Undang Penyiaran sebelumnya, pada Pasal 7 Undang-Undang No. 24 Tahun 1997 yang berbunyi "Penyiaran dikuasai oleh negara yang pembinaan dan pengendaliannya dilakukan oleh pemerintah", menunjukkan bahwa penyiaran pada masa itu merupakan bagian dari instrumen kekuasaan yang digunakan untuk semata-mata bagi kepentingan pemerintah. ${ }^{\mathrm{I}}$

${ }^{1}$ Judhariksawan, Hukum Penyiaran, Cet.II, Raja Grafindo Persada, Jakarta, 2010, hlm. 7 . 
Proses demokratisasi di Indonesia menempatkan publik sebagai pemilik dan pengendali utama ranah penyiaran. Karena frekuensi adalah milik publik dan sifatnya terbatas, maka penggunaannya harus sebesarbesarnya bagi kepentingan publik. Sebesar-besarnya bagi kepentingan publik artinya adalah media penyiaran harus menjalankan fungsi pelayanan informasi publik yang sehat. Informasi terdiri dari bermacammacam bentuk, mulai dari berita, hiburan, ilmu pengetahuan, dan lain-lain. Dasar dari fungsi pelayanan informasi yang sehat adalah seperti yang tertuang dalam Undang-Undang Nomor 32 Tahun 2002 tentang Penyiaran yaitu Diversity of Content (prinsip keberagaman isi) dan Diversity of Ownership (prinsip keberagaman kepemilikan). ${ }^{2}$

Sejak disahkannya Undang-Undang Nomor 32 Tahun 2002 terjadi perubahan fundamental dalam pengelolaan sistem penyiaran di Indonesia, di mana pada intinya adalah semangat untuk melindungi hak masyarakat secara lebih merata. Perubahan paling mendasar dalam semangat undangundang ini adalah adanya limited transfer of authority dari pengelolaan penyiaran yang selama ini merupakan hak ekslusif pemerintah kepada sebuah badan pengatur independen (independent regulatory body) bernama Komisi Penyiaran Indonesia (KPI). Independen yang dimaksudkan adalah untuk mempertegas bahwa pengelolaan sistem penyiaran yang merupakan ranah publik harus dikelola oleh sebuah badan yang bebas dari intervensi modal maupun kepentingan kekuasaan. ${ }^{3}$

Perkembangan industri media informasi di era reformasi dan demokrasi ini berkembang dengan sangat cepat dan pesat sekali, bahkan terkesan tidak terkontrol dengan baik dan serius oleh para penegak hukum. Media cetak maupun elektronik merupakan media massa yang paling banyak digunakan oleh masyarakat di berbagai lapisan sosial, terutama di masyarakat kota. Sebagaimana sifat media informasi, media massa selain mengandung nilai manfaat sebagai alat transformasi, juga sering disalah artikan menjadi media informasi yang ampuh menebarkan nilai-nilai baru yang tidak diharapkan masyarakat itu sendiri dalam artian yang negatif. Untuk meningkatkan daya saing suatu media massa, tak jarang media massa menggunakan berita atau gambar erotika dan/atau porno bahkan menampilkan kekerasan baik berbentuk kekerasan fisik maupun kekerasan psikis sebagai daya tarik media tersebut. Sejalan dengan pesatnya pertumbuhan media penyiaran sehingga kebebasan berekspresi justru mengalami penurunan kontrol sosial baik oleh pemerintah maupun oleh

\footnotetext{
${ }^{2}$ Ibid, hlm. 8 .

${ }^{3}$ Ibid, hlm. 9.
} 
masyarakat sendiri sehingga mengakibatkan terjadinya penurunan moral yang sangat signifikan.

Berkaca pada masalah tersebut, Lembaga yang bertanggung jawab, dalam hal ini adalah Komisi Penyiaran Indonesia sudah seharusnya membatasi para "kreator" di bidang penyiaran khususnya televisi, pembatasan memunculkan aturan-aturan yang berupaya mencegah adanya berita atau gambar erotika dan/atau porno dan kekerasan fisik maupun kekerasan psikis tersebut yang dinamakan Pedoman Perilaku Penyiaran dan Standar Program Siaran ( $P_{3}$ SPS). Harus disadari potensi negatif tidak hanya terdapat di dalam dunia penyiaran, namun juga terdapat pada kegiatan perfilman. Penyiaran sangat identik dengan perfilman karena tak jarang televisi menyuguhi konten yang ada didalamnya dengan film untuk keperluan program acaranya. Film merupakan media komunikasi massa efektif yang dapat merepresentasikan suatu hal baik secara audio maupun visual yang dibuat sehidup dan semenarik mungkin sehingga pesan yang ingin disampaikan oleh "si pembuat" mudah dipahami oleh audience. Selain media komunikasi massa yang efektif, film juga merupakan media multifungsional yang dapat digunakan untuk berbagai tujuan seperti pendidikan, hiburan, komersil, dan lain-lain. Dikarenakan keefektifan dan multifungsionalitas film tersebut maka tidak heran jika film dapat menjaring beragam audience dari berbagai lapisan masyarakat. Pengaturan yuridis mengenai perfilman Indonesia saat ini dituangkan melalui Undang-Undang No. 33 Tahun 2009 tentang Perfilman. Secara yuridis yang dimaksud dengan film sebagaimana definisi undang-undang adalah karya seni budaya yang merupakan pranata sosial dan media komunikasi massa yang dibuat berdasarkan kaidah sinematografi dengan atau tanpa suara dan dapat dipertunjukkan. ${ }^{4}$ Berdasarkan definisi tersebut dapat ditemukan kata-kata bahwa film merupakan karya seni budaya yang merupakan pranata sosial.

Berbicara mengenai pelaksanaan tugas, Komisi Penyiaran Indonesia dengan Lembaga Sensor Film sebenarnya mempunya tugas yang sangat berbeda karena sudah jelas Komisi Penyiaran Indonesia mengatur segala bentuk penyiaran dan Lembaga Sensor Film mengatur mengenai penyensoran dari sebuah film yang ingin diedarkan. Akan tetapi dalam praktek, kedua lembaga ini sangat berkaitan erat dalam pelaksanaan tugasnya. Komisi Penyiaran Indonesia yang merupakan

${ }^{4}$ Pasal 1 ayat (1) Undang-Undang Nomor 33 Tahun 2009 tentang Perfilman. 
lembaga negara yang bersifat independen yang ada di pusat dan di daerah mempunyai wewenang dan tugas: 5

I) Wewenang Komisi Penyiaran Indonesia

a. Menetapkan standar program siaran.

b. Menyusun peraturan dan menetapkan pedoman perilaku penyiaran.

c. Mengawasi pelaksanaan peraturan dan pedoman perilaku penyiaran serta standar program siaran.

d. Memberikan sanksi terhadap pelanggaran peraturan dan pedoman perilaku penyiaran serta standar program siaran.

e. Melakukan koordinasi dan/atau kerjasama dengan Pemerintah, lembaga penyiaran, dan masyarakat.

2) Tugas dan kewajiban Komisi Penyiaran Indonesia

a. Menjamin masyarakat untuk memperoleh informasi yang layak dan benar sesuai dengan hak asasi manusia.

b. Ikut membantu pengaturan infrastruktur bidang penyiaran.

c. Ikut membangun iklim persaingan yang sehat antarlembaga penyiaran dan industri terkait.

d. Memelihara tatanan informasi nasional yang adil, merata, dan seimbang.

e. Menampung, meneliti, dan menindaklanjuti aduan, sanggahan, serta kritik dan apresiasi masyarakat terhadap penyelenggaraan penyiaran.

f. Menyusun perencanaan pengembangan sumber daya manusia yang menjamin profesionalitas di bidang penyiaran.

Sementara itu, Lembaga Sensor Film (LSF) adalah sebuah lembaga yang bertugas menetapkan status edar film-film di Indonesia yang mempunyai wewenang dan tugas: 6

I) Wewenang Lembaga Sensor Film

a. Meluluskan sepenuhnya suatu film dan reklame film untuk di edarkan, diekspor, dipertunjukan, dan/atau ditayangkan kepada umum.

b. Memotong atau menghapus bagian gambar, adegan, suara, dan teks terjemahan dari suati film atau reklame film yang

5 https://72legalogic.wordpress.com/2009/03/27/tugas-dan-kewenangan-komisipenyiaran-indonesia-kpi/, diakses pada Jumat, 13 Februari 2018, Pukul 13.15 WIB.

${ }^{6}$ http://lsf.go.id/sejarahsensor, diakses pada Jumat, 13 Februari 2018, Pukul 13.40 WIB. 
tidak layak untuk dipertunjukan atau ditayangkan kepada umum.

c. Menolak suatu film dan reklame film secara utuh diedarkan, diekspor, dipertunjukan atau ditayangkan kepada umum.

d. Menetapkan penggolongan usia penonton.

e. Memberikan surat izin lulus sensor untuk setiap kopi film, trailer serta film iklan, dan tanda lulus sensor yang dibubuhkan pada reklame film, yang dinyatakan lulus sensor.

f. Membatalkan surat atau tanda lulus sensor untuk suatu film dan reklame film yang ditarik dari peredaran berdasarkan ketentuan Pasal 3I ayat (I) Undang-Undang No. 8 tahun 1992.

2) Tugas Lembaga Sensor Film

a. Melakukan penyensoran terhadap film dan reklame film yang akan diedarkan, diekspor, atau ditayangkan untuk umum.

b. Meneliti tema, gambar, adegan, suara dan teks terjemahan dari suatu film.

c. Menilai layak tidaknya tema, gambar, adegan, suara, dan teks terjemahan dari suatu film.

Pertanyaan yang kemudian muncul di era sekarang adalah, bagaimana jika terdapat film yang menjadi konsumsi publik tidak sesuai dengan pranata sosial di Indonesia? Bagaimana sikap pemerintah untuk menghentikan atau mencegah hal tersebut? Sadar akan hal tersebut maka sudah sepantasnya ada upaya perlindungan bagi masyarkat terhadap dampak suatu film khususnya yang ditayangkan di televisi. Upaya perlindungan tersebut salah satunya adalah dengan penyensoran. Demi merealisasikan kegiatan sensor film tersebut maka, undang-undang tersebut mengamanatkan kelahiran lembaga negara, yaitu Lembaga Sensor Film (LSF) yang berwenang mengeluarkan Surat Tanda Lulus Sensor untuk suatu film. Kemudian pertanyaan lain muncul, bagaimana jika suatu film yang akan menjadi konsumsi publik dan telah mengantongi Surat Tanda Lulus Sensor dari LSF lalu ditayangkan di televisi yang adalah ranah dari KPI? Pertanyaan tersebut menunjukan bahwa hubungan antara kedua lembaga ini sangat berkaitan erat dan tumpang tindih dalam pelaksanaan tugasnya.

\section{PERMASALAHAN}

Berdasarkan latar belakang masalah yang telah diuraikan dapat dirumuskan identifikasi masalah sebagai berikut: 
I. Bagaimana kedudukan dan kewenangan Komisi Penyiaran Indonesia dengan Lembaga Sensor Film dalam struktural ketatanegaraan Indonesia/

2. Bagaimana hubungan Komisi Penyiaran Indonesia dengan Lembaga Sensor Film dalam hal perfilman?

\section{METODOLOGI PENELITIAN}

Penelitian ini menggunakan tipe penelitian yuridis normatif dan yuridis empiris. Yuridis normatif dilakukan dengan cara menelaah dan menginterpretasikan hal-hal yang bersifat teoritis. Adapun yuridis empiris dilakukan dengan penelitian lapangan yang sifatnya wawancara. Penelitian yuridis normatif adalah penelitian yang dilakukan berdasarkan bahan hukum utama dengan cara menelaah teori-teori, konsep-konsep, asas-asas hukum serta peraturan perundang-undangan. Penelitian ini dikenal pula dengan penelitian kepustakaan, yakni dengan mempelajari buku-buku, peraturan perundang-undangan dan dokumen lain yang berhubungan dengan karya ilmiah ini. Penelitian yuridis empiris yakni dilakukan dengan melihat kenyataan yang ada dalam praktek dilapangan. Penelitian ini dikenal pula dengan penelitian secara sosiologis yang dilakukan secara langsung ke lapangan.

\section{PEMBAHASAN}

Kedudukan dan Kewenangan Komisi Penyiaran Indonesia dengan Lembaga Sensor Film dalam Struktural Ketatanegaraan Indonesia.

Lembaga negara independen dianggap penting untuk menjamin tegaknya demokrasi, oleh karena itu, lembaga negara independen merupakan lembaga negara yang diedialkan independen dalam artian bebas dari campur tangan cabang kekuasaan manapun, dan karenanya berada di luar ranah kekuasaan eksekutif, legislatif maupun yudikatif. Namun pada saat yang sama, komisi negara independen memiliki fungsi dan karakter yang bersifat gabungan diantara ketiganya. Dalam bahasa Funk dan Seamon, komisi Negara independen tidak jarang mempunyai kekuasaan quasi legislative, quasi executive dan quasi judicial power. ${ }^{7}$

Menurut teori kelembagaan dari Jimly Asshiddiqie berdasarkan pembedaan dari segi fungsinya lembaga-lembaga negara dapat dikategorikan sebagai organ utama atau organ primer (primary constitutional organs) dan ada pula yang merupakan organ pendukung atau penunjang (auxiliary state organs). Untuk memahami perbedaan diantara keduanya, lembaga-lembaga negara tersebut dapat

${ }^{7}$ Wiliam F. Funk \& Richard H. Seamon, Administrative Law: Examples and Explanations, 2001, hlm. 23-24. 
dibedakan dalam tiga ranah: a) kekuasaan eksekutif atau pelaksana (administrator, bestuurzorg); b) kekuasaan legislatif dan fungsi pengawasan; c) kekuasaan kehakiman atau fungsi yudisial. ${ }^{8}$

I. Komisi Penyiaran Indonesia

a. Kekuasaan Eksekutif

KPI merupakan lembaga negara penunjang yang menjalankan program dan kegiatan baik teknis maupun administrasi terkait penyelenggaraan penyiaran di Indonesia, jika dihubungkan dengan teori tentang kelembagaan negara yang menyebutkan bahwa lembaga negara dapat dibedakan menurut fungsinya, KPI termasuk lembaga negara penunjang yang menjalankan fungsi eksekutif (pelaksana administratif), hal ini tertuang dalam Undang-Undang Nomor 32 tahun 2002 tentang Penyiaran Pasal 8 ayat (3), ketentuan tersebut menjelaskan bahwa KPI memiliki tugas dan kewajiban menjamin masyarakat untuk memperoleh informasi yang layak dan benar sesuai dengan hak asasi manusia, ikut membantu pengaturan infrastruktur bidang penyiaran, memelihara tatanan informasi nasional yang adil, merata, dan seimbang serta menyusun perencanaan pengembangan sumber daya manusia yang menjamin profesionalitas di bidang penyiaran. Dalam menjalankan fungsi, wewenang ,tugas dan kewajibannya, KPI Pusat bertanggung jawab kepada Presiden dan menyampaikan laporan kepada DPR, sesuai dengan ketentuan Pasal 53 ayat (I) Undang-Undang Nomor 32 tahun 2002 tentang Penyiaran.

b. Kekuasaan Legislatif

Sistem pengawasan dan kekuasaan legislatif ketatanegaraan Indonesia dipegang oleh tiga lembaga negara, yaitu Dewan Perwakilan Rakyat (DPR), Dewan Perwakilan Daerah (DPD) dan Majelis Permusyawaratan Rakyat (MPR). Jika dikaitkan dengan fungsi pengawasan dan pelaksanaan kekuasaan legislatif, KPI menjalankan fungsi legislasi (pembuat peraturan perundang-undangan), yaitu dalam menjalankan fungsinya, KPI mempunyai wewenang menyusun peraturan dan menetapkan pedoman perilaku penyiaran, kewenangan tersebut dinyatakan dalam Pasal 8 ayat (2) huruf a Undang-Undang Nomor 32 tahun 2002 tentang Penyiaran. Selain fungsi legislasi KPI juga memiliki fungsi pengawasan, fungsi pengawasan yang dilakukan oleh KPI adalah mengawasi pelaksanaan peraturan dan pedoman perilaku penyiaran serta standar program siaran, kewenangan tersebut

${ }^{8}$ Jimly Asshiddiqie, Perkembangan \& Konsolidasi Lembaga Negara Pasca Reformasi, Sinar Grafika, Jakarta, 2006, hlm. 113. 
dinyatakan dalam Pasal 8 ayat (2) huruf b Undang-Undang Nomor 32 tahun 2002 tentang Penyiaran.

KPI bukanlah cabang dari MPR, DPR, atau DPD. Menurut Pasal 2 UUD 1945 menyatakan bahwa MPR terdiri dari anggota DPR dan anggota DPD yang dipilih melalui pemilu. Jadi lembaga-lembaga yang menjalankan fungsi legislatif dan pengawasan menurut UUD 1945 ada tiga yaitu MPR, DPR dan DPD, dalam arti KPI bukan cabang dari kekuasaan ketiga lembaga tesebut. KPI menjalankan fungsi legislasi dan pengawasan sesuai dengan kewenangannya menurut UndangUndang Nomor 32 tahun 2002 tentang Penyiaran.

KPI merupkan salah satu unsur pengawas masyarakat. Dalam sistem pemerintahan Indonesia pengawasan dapat dilakukan lembagalembaga diluar organ pemerintahan (pengawasan eksternal) dan dapat pula dilakukan oleh lembaga-lembaga dalam lingkungan pemerintahan itu sendiri (pengawasan internal). KPI bertindak sebagai pengawas eksternal pemerintahan. Subjek yang diawasi oleh KPI yaitu lembaga atau perseorangan yang tugas pokoknya berkaitan dengan penyelengaraan penyiaran, antara lain Lembaga Penyiaran Publik (LPP), Lembaga Penyiaran Swasta (LPS), Lembaga Penyiaran Komunitas (LPK), Lembaga Penyiaran Berlangganan (LPB). Mengenai kedudukan KPI dalam sistem pengawasan masyarakat, menurut Pasal 8 ayat (I) Undang-Undang Nomor 32 tahun 2002 tentang Penyiaran menyatakan bahwa KPI merupakan wujud peran serta masyarakat berfungsi mewadahi aspirasi serta mewakili kepentingan masyarakat akan penyiaran, dalam melakukan fungsi pengawasan, KPI bertugas menerima laporan atas aduan, sanggahan serta kritik dan apresiasi masyarakat terhadap penyelenggaraan penyiaran, kemudian menampung, meneliti dan menindaklanjuti laporan tersebut. Berdasarkan pemaparan tersebut, dapat dilihat bahwa KPI menjalankan fungsinya sebagai lembaga legislasi dan pengawas, maka dapat disimpulkan bahwa KPI merupakan lembaga penunjang (auxiliary state organ) yang memiliki fungsi legislatif.

c. Kekuasaan Yudikatif

Lembaga pelaksana atau pelaku dalam bidang kekuasaan kehakiman ada dua yaitu Mahkamah Konstitusi dan Mahkamah Agung beserta badan peradilan yang berada di bawahnya dalam lingkungan peradilan umum, lingkungan peradilan agama, lingkungan peradilan militer, lingkungan peradilan tata usaha negara, disamping keduanya ada pula Komisi Yudisial sebagai lembaga pengawas martabat, kehormatan, dan perilaku hakim. 
KPI tidak termasuk kategori lembaga penunjang (auxiliary state organs) yang berada dalam ranah kekuasaan kehakiman, meskipun KPI mempunyai fungsi penegakan hukum khususnya penyelenggaraan penyiaran, namun KPI tidak berwenang menjatuhkan sanksi baik pidana maupun perdata. Dengan demikian KPI bukanlah lembaga peradilan, kedudukan KPI lebih merupakan lembaga administratif karena kewenangan yang melekat padanya adalah kewenangan administratif, sehingga sanksi yang dijatuhkan merupakan sanksi administratif. Sehingga dapat disimpulkan bahwa KPI bukan merupakan lembaga yang memiliki fungsi yudikatif.

Penjelasan diatas jelas menunjukan bahwa Komisi Penyiaran Indonesia adalah Lembaga Independen yang lahir dari undang-undang yaitu Undang-Undang No. 32 Tahun 2002 tentang Penyiaran yang tugasnya lebih berfokus pada pengawasan siaran-siaran yang menjadi konsumsi masyarakat agar tetap berada dijalur yang benar.

2. Lembaga Sensor Film

a. Kekuasaan Eksekutif

Lembaga Sensor Film merupakan Lembaga Indpenden Non Struktural. Jika dihubungkan dengan teori tentang kelembagaan negara yang menyebutkan bahwa lembaga negara dapat dibedakan menurut fungsinya, LSF termasuk lembaga negara penunjang yang menjalankan fungsi eksekutif (pelaksana administratif), hal ini tertuang dalam Peraturan Pemerintaah No. I8 Tahun 2014. Ketentuan tersebut menjelaskan bahwa LSF memiliki tugas sebagai pelindung masyarakat dari dampak negatif yang timbul dari peredaran dan pertunjukan film dan iklan film yang tidak sesuai dengan dasar, arah, dan tujuan perfilman Indonesia.

b. Kekuasaan Legislatif

Jika dikaitkan dengan fungsi pengawasan dan pelaksanaan kekuasaan legislatif, LSF menjalankan fungsi legislasi karena LSF merupakan badan yang melakukan penyensoran setiap film dan iklan film. ${ }^{9}$ LSF merupkan salah satu unsur pengawas masyarakat karena dalam sistem pemerintahan Indonesia pengawasan dapat dilakukan lembaga-lembaga diluar organ pemerintahan (pengawasan eksternal) dan dapat pula dilakukan oleh lembaga-lembaga dalam lingkungan pemerintahan itu sendiri (pengawasan internal). LSF bertindak sebagai pengawas eksternal pemerintahan. Subjek yang diawasi oleh LSF yaitu film/iklan film yang akan menjadi konsumsi publik.

${ }^{9}$ Peraturan Pemerintah No 18 Tahun 2014, Pasal 1 Aayat (4). 
c. Kekuasaan Yudikatif

Sama seperti KPI, LSF tidak termasuk kategori lembaga penunjang (auxiliary state organs) yang berada dalam ranah kekuasaan kehakiman, meskipun LSF mempunyai fungsi penegakan hukum khususnya penyelenggaraan perfilman, namun LSF tidak berwenang menjatuhkan sanksi baik pidana maupun perdata.

Lembaga Sensor Film (LSF) merupakan lembaga yang bersifat tetap dan independen yang berkedudukan di Ibukota Negara Republik Indonesia. Selain itu, LSF berada di bawah dan bertanggung jawab kepada Presiden melalui Menteri Pendidikan dan Kebudayaan. Peraturan Pemerintah No. I8 Tahun 2014 ini juga menegaskan, LSF dalam membentuk perwakilan di ibukota provinsi. Pembentukannya harus berdasarkan kriteria yang ditetapkan oleh LSF. Sementara sebelumnya Peraturan Pemerintah No. 7 Tahun 1994 disebutkan, LSF sebagaimana dimaksud merupakan lembaga non struktural yang berkedudukan di Ibukota Negara Republik Indonesia.

Penjelasan diatas menunjukan bahwa kedudukan dari KPI lebih diatas dari LSF karena menurut hierarkinya, KPI yang dibentuk berdasarkan undang-undang lebih tinggi dari pada LSF yang dibentuk berdasarkan Peraturan Pemerintah. Penjelasan tersebut sejalan dengan hasil penelitian penulis yang sifatnya wawancara dengan staff Lembaga Sensor Film yaitu Ibu Octa. Beliau tidak membantah bahwa kedudukan LSF lebih dibawah KPI.

"Memang jika melihat dari segi struktural, Lembaga Sensor Film dibawah dari KPI walaupun kedua lembaga sama-sama Lembaga Independen. Lembaga Sensor Film dinaungi langsung oleh Kementerian Pendidikan dan Kebudayaan". ${ }^{\text {ro }}$

\section{Hubungan Komisi Penyiaran Indonesia dengan Lembaga Sensor Film dalam hal Perfilman}

Negara Indonesia adalah negara hukum, itulah yang tercantum dalam Pasal I ayat 3 Undang-Undang Dasar 1945 Amandemen ke-3. UUD I945 yang merupakan hukum dasar tertulis Indonesia. Dalam suatu negara hukum hak-hak asasi manusia diakui dan dilindungi. Oleh karena itu dibuat peraturan-peraturan yang diupayakan agar dapat melindungi hakhak warga negaranya. Berbagai bidang kehidupan dalam kehidupan bernegara ini diatur dalam peraturan perundang-undangan. Begitu juga

${ }^{10}$ Hasil wawan cara dengan Ibu Octa, Staf LembG Sensor Film, Pada tanggal 16 Juli 2018, pukul 13.00 WIB, 
bidang perfilman yang mempunyai pengaturan sendiri (self regulation). Regulasi sendiri ini sesungguhnya bermaksud untuk menentukkan tolak ukur sesungguhnya atau standar (minimum) perilaku tertentu bagi perusahaan-perusahaan atau pelaku-pelaku usaha yang terikat atau tunduk padanya. ${ }^{\text {II }}$

Apabila regulasi perfilman sendiri tumbuh dan berkembang secara positif, dipadu dengan bekerjanya peraturan perundang-undangan tertentu berkaitan dengan kepentingan-kepentingan konsumen, maka upaya para para pelaku usaha tersebut merupakan pula hal yang membantu perlindungan konsumen juga. suatu kondisi yang sangat menguntungkan bagi konsumen apabila semua pihak, khusunya pelaku usaha, menjalankan dan menaati hukum yang berlaku serta disamping itu, mempunyai moral yang tinggi dalam mengejar tujuan usaha yang dijalankannya. ${ }^{12}$

Film sendiri tidak bisa dipisahkan dari dunia penyiaran khususnya televisi. Televisi merupakan suatu media elektronik yang menjembatani masyarakan (konsumen) dengan tayangan-tayangannya. Tidak sedikit pula televisi mempertontonkan film sebagai program siarannya. Itu berarti KPI sebagai induk penyiaran di Indonesia berjalan beriringan dengan LSF sebagai 'aktor' utama dalam masuknya film ke Indonesia. Hubungan KPI dengan LSF dalam menjalankan tugasnya masing-masing juga bisa dikatakan berkaitan karena suatu film yang akan masuk ke televisi yang merupakan ranah dari KPI harus mendapat Surat Tanda Lulus Sensor terlebih dahulu dari LSF. Akan tetapi bagaimana jika suatu film yang akan menjadi konsumsi publik dan telah mengantongi Surat Tanda Lulus Sensor dari LSF lalu ditayangkan di televisi yang adalah ranah dari KPI tetapi dinilai tidak layak tayang. Pertanyaan tersebut menunjukan bahwa hubungan antara kedua lembaga ini sangat berkaitan erat tetapi tumpang tindih dalam pelaksanaan tugasnya.

Bila dilihat dari segi hierarki ketatanegaraan di Indonesia, KPI berhak untuk meminta pertanggungjawaban dari LSF karena kedudukan KPI diatas dari LSF. KPI juga dapat menolak film tidak layak tayang tersebut untuk tidak di pertontonkan di televisi. Bila film tersebut sudah dipertontonkan, maka KPI berhak menindak lanjuti stasiun televisi yang mempertontonkan film tidak layak tayang tersebut dengan memberikan sanksi sesuai dengan regulasi yang ada di KPI.

\section{KESIMPULAN}

${ }^{11}$ Nasution, AZ, Hukum Perlindungan Konsumen Suatu Pengantar, Diadid Media, Jakarta, 2006, hlm 20.

${ }^{12}$ Ibid. 
Berdasakan uraian-uraian pada bab sebelumnya mengenai kedudukan dan kewenangan Komisi Penyiaran Indonesia dengan Lembaga Sensor Film, maka dapat ditarik beberapa kesimpulan sebagai berikut :

I. Komisi Penyiaran Indonesia dalam rangka menjalankan fungsinya memiliki kewenangan menyusun dan mengawasi berbagai peraturan penyiaran yang menghubungkan antara lembaga penyiaran, pemerintah dan masyarakat. Pengaturan tersebut mencakup semua proses kegiatan penyiaran, mulai dari tahap pendirian, operasionalisasi, pertanggungjawaban dan evaluasi. Komisi Penyiaran Indonesia memiliki tugas dan kewajiban menjamin masyarakat untuk memperoleh informasi yang layak dan benar. Lembaga Sensor Film dalam menjalankan fungsinya melindungi masyarakat dari pengaruh negatif sebuah film. Dalam menjamin kepastian hukum di bidang perfilman, kedudukan dan kewenangan Komisi Penyiaran Indonesia dengan Lembaga Sensor Film bila dilihat dari segi hierarki, Komisi Penyiaran Indonesia berhak untuk meminta pertanggungjawaban dari Lembaga Sensor Film karena kedudukan Komisi Penyiaran Indonesia diatas dari Lembaga Sensor Film. KPI juga dapat menolak film tidak layak tayang tersebut untuk tidak di pertontonkan di televisi. Bila film tersebut sudah dipertontonkan, maka Komisi Penyiaran Indonesia berhak menindak lanjuti stasiun televisi yang mempertontonkan film tidak layak tayang tersebut dengan memberikan sanksi sesuai dengan regulasi yang ada di Komisi Penyiaran Indonesia.Film sendiri tidak

2. merupakan suatu media elektronik yang menjembatani masyarakan dengan tayangan-tayangannya. Tidak sedikit pula televisi mempertontonkan film sebagai program siarannya. Itu berarti Komisi Penyiaran Indonesia sebagai induk penyiaran di Indonesia berjalan beriringan dengan Lembaga Sensor Film sebagai 'aktor' utama dalam masuknya film ke Indonesia. Hubungan Komisi Penyiaran Indonesia dengan Lembaga Sensor Film dalam menjalankan tugasnya masingmasing juga bisa dikatakan berkaitan karena suatu film yang akan masuk ke televisi yang merupakan ranah dari Komisi Penyiaran Indonesia harus mendapat Surat Tanda Lulus Sensor terlebih dahulu dari Lembaga Sensor Film.

\section{DAFTAR PUSTAKA}

Abdulkadir Muhammad, Hukum dan Penelitian Hukum, PT.Citra Aditya Bakti, Bandung, 2004. 
A Gunawan Setiardja, Dialektika Hukum dan Moral dalam Pembangunan Masyarakat Indonesia, Kanisius, Yogyakarta, 1990.

Indroharto, Asas-Asas Umum Pemerintahan yang Baik, Citra Aditya Bakti, Bandung, 1994.

Jimly Asshiddiqie, Perkembangan \& Konsolidasi Lembaga Negara Pasca Reformasi, Cet.2., Setjen dan Kepaniteraan MKRI, Jakarta, Sinar Grafika, 2006.

- Perkembangan \& Konsolidasi Lembaga Negara Pasca Reformasi, Edisi II, Cet.2., Sinar Grafika, Jakarta, 2012.

Perkembangan \& Konsolidasi Lembaga Negara Pasca Amandemen, Sinar Grafika, Jakarta, 2oı.

- Menjaga Denyut Nadi Konstitusi: Refleksi Satu Tahun Mahkamah Konstitusi, Konstitusi Press, Jakarta, 2004.

Konstitusi dan Konstitusionalisme Indonesia, Sinar Grafika, Jakarta, 20II.

Judhariksawan, Hukum Penyiaran, Cet.II, Raja Grafindo Persada, Jakarta, 2010.

Mahmud MD, Hukum dan Pilar-Pilar Demokrasi, Gama Media, Yogyakarta, 1999.

Miriam Budiardjo, Dasar-Dasar Ilmu Politik, Gramedia Pustaka Utama, Jakarta, 1998.

Nasution, AZ, Hukum Perlindungan Konsumen Suatu Pengantar, Diadid Media, Jakarta, 2006,

Riduan Syahrani, Kata - Kata Kunci Mempelajari Ilmu Hukum, P.T. Alumni, Bandung, 2009.

Soerjono Soekanto, Pengantar Penelitian Hukum, UI Press, Jakarta, 2 oı.

Suwoto Mulyosudarmo, Kekuasaan dan Tanggung Jawab Presiden Republik Indonesia, Suatu Penelitian Segi-Segi Teoritik dan Yuridis Pertanggungjawaban Kekuasaan, Universitas Airlangga, Surabaya, 1990.

Sunaryati Hartono, Penelitian Hukum di Indonesia pada akhir abad ke-2o, Alumni, Bandung, 2006.

Sugiyono, Metode Penelitian Pendidikan: Pendekatan Kuantitatif, Kualitatif dan R\&D, Alfabeta, Bandung, 2009.

Wiliam F. Funk \& Richard H. Seamon, Administrative Law: Examples and Explanations, 200I

Zainal Arifin Mochtar, Lembaga Negara Independen, Raja Grafindo Persada, Jakarta, 2016. 
Asip Suyadi

Undang-Undang Dasar Negara Republik Indonesia Tahun 1945.

Undang-Undang Nomor 32 Tahun 2002 tentang Penyiaran

Undang-Undang Nomor 33 Tahun 2009 tentang Perfilman.

Peraturan Pemerintah Republik Indonesia Nomor i8 Tahun 2014 tentang Lembaga Sensor Film.

Peraturan Komisi Penyiaran Indonesia tentang Pedoman Perilaku Penyiaran.

Peraturan Komisi Penyiaran Indonesia tentang Standar Program Siaran.

Peraturan Komisi Penyiaran Indonesia tentang Kelembagaan Komisi Penyiaran Indonesia. 
